\title{
PENGARUH KOMITE AUDIT DAN KEPEMILIKAN INSTITUSIONAL PADA PERSISTENSI LABA PERUSAHAAN MANUFAKTUR
}

\author{
I Made Sujana ${ }^{1}$ \\ Gerianta Wirawan Yasa ${ }^{2}$ \\ I Dewa Nyoman Badera ${ }^{3}$ \\ ${ }^{1}$ Fakultas Ekonomi dan Bisnis Universitas Udayana, Bali, Indonesia \\ Email: tax.madesujana@yahoo.com \\ ${ }^{2}$ Fakultas Ekonomi dan Bisnis Universitas Udayana, Bali, Indonesia \\ ${ }^{3}$ Fakultas Ekonomi dan Bisnis Universitas Udayana, Bali, Indonesia
}

\begin{abstract}
ABSTRAK
Penelitian ini menguji pengaruh komite audit dan kepemilikan institusional pada persistensi laba. Penelitian ini menggunakan teknik analisis regresi (multiple regression) dengan membandingkan koefisien determinasi antara dua variabel independen. Data yang digunakan dalam penelitian ini adalah data sekunder yang dipublikasikan di BEI dengan menggunakan 77 sampel perusahaan manufaktur periode 2011 - 2012.Hasil analisis menunjukkan bahwa komite audit berpengaruh negatif pada persistensi laba, sedangkan kepemilikan institusional berpengaruh positif pada persistensi laba. Komite audit berpengaruh negatif pada persistensi laba kemungkinan disebabkan oleh semakin banyak jumlah komite audit yang dimiliki maka persistensi laba akan cenderung menurun Kepemilikan institusional berpengaruh positif pada persistensi laba mengandung arti bahwa semakin banyak jumlah saham yang dimiliki pemegang saham institusi, maka persistensi laba akan cenderung meningkat.
\end{abstract}

Kata kunci: Komite Audit, Kepemilikan Institusional, Persistensi Laba

\begin{abstract}
This study examined the effect of the audit committee and institutional ownership on earnings persistence. This study uses regression analysis techniques (multiple regression) by comparing the coefficient of determination between the two independent variables. The data used in this research is secondary data published on the Stock Exchange using 77 samples of manufacturing firms the period 2011-2012.The analysis showed that audit committees have negative effect on the persistence of earnings, while institutional ownership has a positive effect on earnings persistence. The audit committee has a negative effect on earnings persistence may be caused by the greater number of the audit committee are owned by the persistence of earnings will tend to decline. Institutional ownership has a positive effect on earnings persistence implies that the greater number of shares owned by institutional shareholders, the persistence of earnings will tend to increase.
\end{abstract}

Keywords: Audit Committee, Institutional Ownership, Earnings Persistence 


\section{PENDAHULUAN}

Para pelaku pasar modal memerlukan informasi untuk mengambil keputusan investasi. Informasi yang diperlukan tersebut diantaranya berupa laporan keuangan yang dipublikasikan oleh perusahaan publik. Standar Akuntansi Keuangan (PSAK) No. 1 menyatakan bahwa tujuan laporan keuangan adalah memberikan informasi tentang posisi keuangan, kinerja dan arus kas perusahaan yang bermanfaat bagi sebagian besar kalangan pengguna laporan dalam rangka membuat keputusan-keputusan ekonomi serta menunjukkan pertanggungjawaban manajemen atas penggunaan sumber-sumber daya yang dipercayakan kepada mereka (IAI, 2014).

Selama ini laba akuntansi masih menarik perhatian para investor sebagai dasar pengambilan keputusan, seperti pengambilan keputusan untuk membeli atau menjual saham suatu perusahaan, pembagian dividendan lain sebagainya. Oleh karena itu laba yang perlu diperhatikan oleh para calon maupun investor bukan hanya laba yang tinggi, namun juga laba yang persisten.Darraough (1993) menunjukkan arti pentingnya informasi laba dengan menyatakan bahwa perusahaan memberikan laporan keuangan kepada berbagai pihak yang berkepentingan atau stakeholder, dengan tujuan untuk memberikan informasi kinerja yang relevan dan tepat waktu agar berguna dalam pengambilan keputusan investasi, monitoring, penghargaan kinerja, dan pembuatan kontrak. Agar dapat memberikan informasi yang handal maka laba harus persisten.

Penman dan Zhang (2002) mendefinisikan persistensi laba sebagai revisi laba akuntansi yang diharapkan di masa mendatang (expected future earnings) 
yang disebabkan oleh inovasi laba tahun berjalan (current earnings). Persistensi laba tersebut ditentukan oleh komponen akrual dan aliran kas yang terkandung dalam laba saat ini (Penman, 2001). Bernstein dalam Sloan (1996) menyatakan bahwa komponen akrual dari current earnings cenderung kurang terulang lagi atau kurang persisten untuk menentukan laba masa depan karena mendasarkan pada akrual, deferred (tangguhan), alokasi dan penilaian yang mempunyai distorsi subyektif.

Menurut Wijayanti (2006) laba yang persisten adalah laba yang dapat mencerminkan kelanjutan laba (sustainable earnings) di masa depan yang ditentukan oleh komponen akrual dan aliran kasnya. Sedangkan Chandarin (2001) mengungkapkan bahwa laba yang persisten adalah laba akuntasi yang memiliki sedikit atau tidak mengandung gangguan (noise), dan dapat mencerminkan kinerja keuangan perusahaan yang sesungguhnya. Hal ini memperkuat pendapat Hayn (1995) yang menyatakan bahwa gangguan laba akuntansi disebabkan oleh peristiwa transitori (transitory event) atau penerapan konsep akrual dalam akuntansi.

Persistensi laba memfokuskan pada koefisien dari regresi laba sekarang terhadap laba mendatang. Hubungan tersebut dapat dilihat dari koefesien slope regresi antara laba sekarang dengan laba mendatang. Semakin tinggi (mendekati angka 1) koefisiennya menunjukan persistensi laba yang dihasilkan tinggi, sebaliknya jika nilai koefisien mendekati nol, persistensi labanya rendah atau laba transitorinya tinggi. Jika nilai koefisiennya bernilai negatif, pengertiannya 
terbalik, yaitu nilai koefisien yang lebih tinggi menunjukkan kurang persisten, dan nilai koefisien yang lebih rendah menunjukkan lebih persisten.

Gambaran diatas menunjukkan persistensi laba menjadi penting mengingat persistensi laba berhubungan dengan kinerja keseluruhan perusahaan yang tergambarkan dalam laba perusahaan. Pengertian persistensi laba pada prinsipnya dapat dipandang dalam dua sudut pandang. Pandangan pertama menyatakan bahwa persistensi laba berhubungan dengan kinerja keseluruhan perusahaan yang tergambarkan dalam laba perusahaan. Pandangan ini menyatakan laba yang persisten tinggi terefleksi pada laba yang dapat berkesinambungan (sustainable) untuk suatu periode yang lama. Menurut Schipper (2004)pandangan ini berkaitan erat dengan kinerja perusahaan yang diwujudkan dalam laba perusahaan yang diperoleh pada tahun berjalan. Laba yang persisten jika laba tahun berjalan dapat menjadi indikator yang baik untuk laba perusahaan di masa yang akan datang (Lev dan Thiagarajan 1993; Richardson etal,2001; Penman dan Zhang 2002; Beneish dan Vargus 2002; Richardson 2003) atau berasosiasi kuat dengan arus kas operasi di masa yang akan datang (Dechow dan Dichev 2002 dan Cohen 2003).

Pandangan kedua menyatakan persistensi laba berkaitan dengan kinerja harga saham pasar modal yang diwujudkan dalam bentuk imbal hasil, sehingga hubungan yang semakin kuat antara laba perusahaan dengan imbal hasil bagi investor dalam bentuk return saham menunjukkan persistensi laba yang tinggi (Ayres 1994). Pandangan kedua ini juga menyatakan bahwa persistensi laba berkaitan dengan kinerja saham perusahaan di pasar modal. Hubungan yang 
semakin kuat antara laba dengan imbalan pasar menunjukkan persistensi laba tersebut semakin tinggi (Lev dan Thiagarajan 1993; Chan et al,2004). Hal ini yang membuat persistensi laba menjadi penting karena persistensi laba merupakan salah satu perhitungan acuan dalam pengambilan keputusan.

Barth dan Hutton (2001) dalam studinya menjelaskan bahwa persistensi laba ini merupakan salah satu unsur nilai prediksi dari kualitas informasi akuntansi. Selanjutnya mereka menggunakan persistensi laba sebagai karakteristik nilai relevan dalam model penelitiannya. Persistensi laba dipilih karena sangat relevan dalam perspektif kegunaan keputusan dan mencerminkan tujuan dari informasi akuntansi, seperti yang tercantum dalam Conceptual Framework FASB. Tujuan tersebut adalah memberikan informasi yang berguna bagi pembuatan keputusan oleh investor dan investor potensial serta oleh kreditor dan kreditor potensial. Penelitian sebelumnya di Indonesia menggunakan indikator earning response coefficient untuk mengukur persistensi laba. (Chandarin. 2001).

Laporan laba sebagai produk informasi yang dihasilkan perusahaan tidak terlepas dari prosespenyusunannya yang melibatkan pihak pengelola dalam pengelolaanperusahaan, di antaranya adalah pihak manajemen dan dewan komisaris. Kebijakan dan keputusan yang diambil dalam rangka proses penyusunan laporan keuangan terutama laba akan menentukan kualitas laba. Perbedaan informasi yang diperoleh antara para pemegang saham dengan pihak manajemen perusahaan terkadang menjadi pemicu tidak terwujudnya harapan di atas. Perbedaan informasi ini merupakan kenyataan empiris yang tidak dapat dihindari dari sebuah hubungan keagenan (Khafid, 2012). 
Diperlukan suatu mekanismepengendalian untuk kondisi seperti di atas sehingga perbedaan kepentingan antara kedua belah pihak dapat disejajarkan, melalui mekanisme corporate governance, khususnya komite audit. Bila konsep ini diterapkan dengan baik, maka diharapkan pertumbuhan ekonomi akan terus menanjak seiring dengan meningkatnya transparansi pengelolaan perusahaan yang semakin baik dan dapat menguntungkan banyak pihak (Setyo, 2013).Peran komite audit sebagai komite penunjang tugas dewan komisaris adalah membantu dewan komisaris untuk memastikan bahwa, (a) laporan keuangan disajikan secara wajar sesuai dengan prinsip akuntansi yang berlaku umum, (b) struktur pengendalian internal perusahaan dilaksanakan dengan baik, (c) pelaksanaan audit internal maupun eksternal dilaksanakan sesuai dengan standar audit yang berlaku, dan (d) tindak lanjut temuan hasil audit dilaksanakan oleh manajemen.

Penelitian-penelitian di Indonesia yang mengulas tentang persistensi laba yang terkait dengan komite audit dan kepemilikan institusional menunjukan hasil yang tidak konsisten antara penelitian yang dilakukan di Indonesia dengan penelitian yang dilakukan di luar Indonesia. Ketidak konsistenan hasil tersebut memotivasi penulis melakukan penelitian lebih lanjut tentang pengaruh komite audit terhadap persistensi laba yang akan lebih menekankan pada karakteristik komite auditnya. Penelitian yang akan dilakukan ini difokuskan untuk menganalisis pengaruh komite audit dan kepemilikan institusional terhadap persistensi laba. Alasan memilih variabel komite audit dan kepemilikan institusional karena kedua variabel tersebut merupakan komponen atau bagian dari good corporate governance. Dalam good corporate governance, komite audit 
bertanggungjawab untuk mengawasi proses pelaporan keuangan perusahaan dan meningkatkan prosedur pengendalian internal. Tugas dan tanggungjawab seperti itu maka komite audit dapat mengendalikan manajemen khususnya dalam hal menyelewengkan laba. Penelitian yang dilakukan oleh Chtourou, et al., (2001) dan Klien (2002), yang menguji tentang pengaruh independensi komite audit pada persistensi laba, menyatakan bahwa proporsi direktur, komite audit mempunyai pengaruh positif dengan persistensi laba.

Kepemilikan institusional mempunyai sumberdaya, kemampuan dan kesempatan untuk memantau dan mendisiplinkan manajer agar lebih terfokus pada nilai perusahaan (Siregar dan Utama, 2005 serta Kusumaningtyas, 2012). Keberadaan pemilik institusional dapat menunjukan makanisme corporate governance yang kuat yang dapat digunakan untuk memonitor manajemen perusahaan. Pengaruh kepemilikan institusional terhadap manajemen perusahaan dapat menjadi sangat penting serta dapat digunakan untuk menyelaraskan kepentingan manajemen dengan para pemegang saham (Solomon dan Solomon, 2004 dalam Sutojo, 2005).

Kepemilikan institusional merupakan bagian lain dari corporategovernance, karena institusi mempunyai sumber daya, kemampuan dan kesempatan untuk memantau dan mendisiplinkan manajer agar lebih terfokus pada nilai perusahaan (Siregar dan Utama, 2005). Presentase saham tertentu yang dimiliki oleh institusi dapat mempengaruhi proses penyusunan laporan keuangan yang tidak menutup kemungkinan terdapat akrualisasi sesuai kepentingan pihak manajemen (Boediono, 2005). Guercio dan Hawkins (1999) dan Hartzell dan 
Starks dalam Cornett,et al., (2006) menemukan adanya bukti yang menyatakan bahwa tindakan pengawasan yang dilakukan oleh sebuah perusahaan dan pihak investor institusional dapat membatasi perilaku oportunistik manajer. Dengan demikian, tindakan pengawasan perusahaan yang dilakukan oleh pihak kepemilikan institusional dapat mendorong manajer untuk lebih memfokuskan perhatiannya terhadap kinerja perusahaan sehingga akan membatasi perilaku manajer di dalam persistensi laba.

Berdasarkan hasil penelitian menunjukkan bahwa kepemilikan manajerial berpengaruh terhadap persistensi laba, namun tidak konsisten hasilnya. Studi yang dilakukan Yonatan (2012) mengemukakan bahwapersentase kepemilikan manajerial berpengaruh positif terhadap kualitas laba. Muid (2009) menyatakan bahwa kepemilikan manajerial secara positif dan signifikan mempengaruhi kualitas laba.Boediono (2005) yang menyatakan bahwa kepemilikan manajerial memberikan pengaruh positif terhadap kualitas laba. Besar kecilnya persentase kepemilikan manajerial dapat mempengaruhi kualitas laba suatu perusahaan, karena dengan semakin besarnya persentase kepemilikan manajerial dalam perusahaan, maka akan menempatkan manajer sebagai salah satu pemilik perusahaan, sehingga manajer semakin memiliki peranan untuk meningkatkan kualitas perusahaannya termasuk kualitas laba dalam perusahaan. Dengan kata lain, semakin besar kepemilikan saham oleh manajer maka laba yang dilaporkan akan semakin berkualitas.

Hasil penelitian yang bertolak belakang dengan penelitian di atas adalah penelitian Fibri (2013) yang menunjukkan bahwa kepemilikan manajerial tidak 
mempunyai hubungan yang signifikan terhadap kualitas laba. Hal ini dikuatkan hasil penelitian Verdana Sari (2013) yang menunjukkan bahwa kepemilikan institusional, proporsi dewan komisaris indevenden, kepemilikan manajerial, dan komite audit tidak berpengaruh terhadap kualitas laba. Fathia Anissa (2012) juga mengungkapkan bahwa komite audit dan kepemilikan institusional tidak berpengaruh pada kualitas laba.

Berdasarkan hasil penelitian terdahulu variabel komite audit dan kepemilikan institusional pengaruhnya tidak konsisten pada persistensi laba, sehingga penting dilakukan penelitian ulang dengan menggunakan variabel komite audit dan kepemilikan institusional.

Khafid (2012) meneliti pengaruh tata kelola perusahaan (Corporate Governance) dan struktur kepemilikan terhadap persentasi laba membuktikan bahwa komite audit berpengaruh terhadap persistensi laba. Hasilnya menunjukkan bahwa komite audit berpengaruh pada persistensi laba. Komite audit merupakan salah satu organ yang dibentuk dalam rangka upaya menciptakan good corporate governance yang diharapkan mempengaruhi kualitas laba yang dilaporkan oleh perusahaan. Peraturan Badan Pengawas Pasar Modal nomor IX.I.5 tanggal 24 September 2004 menyatakan bahwa komite audit adalah komite yang dibentuk oleh dewan komisaris dalam rangka membantu melaksanakan tugas dan fungsinya. Hasil penelitian ini senada dengan temuan penelitian Lin, dkk (2006) yang menyatakan bahwa terdapat pengaruh negatif antara ukuran komite audit dengan terjadinya earnings restatement (sebagai proksi yang dipilih dalam mengukur kualitas laba). Artinya semakin banyak jumlah komite audit, maka 
semakin kecil kemungkinan perusahaan melakukan earnings restatement atau semakin tinggi kualitas laba yang dilaporkan. Berdasarkan uraian tersebut di atas, maka peneliti mengajukan hipotesis $\mathrm{H}_{1}$ sebagai berikut :

$\mathrm{H}_{1}$ : Komite audit berpengaruh positif pada persistensi laba

Kepemilikan institusional memiliki kemampuan untuk mengendalikanpihak manajemen melalui proses monitoring secara efektif sehingga dapat mempengaruhi persistensi laba. Persentase saham tertentu yang dimiliki oleh institusi dapat mempengaruhi proses penyusunan laporan keuangan yang tidak menutup kemungkinan terdapat akrualisasi sesuai kepentingan pihak manajemen (Boediono, 2005). Pendapat yang serupa juga disampaikan oleh Cornertt et al.,(2006) yang menyimpulkan bahwa tindakan pengawasanperusahaan oleh kepemilikan institusional dapat mendorong manajer untuk lebih memfokuskan perhatiannya terhadap kinerja perusahaan sehingga akan mengurangi perilaku opportunistik atau mementingkan diri sendiri. Balsam et al., (2002) dalam Siregar dan Utama (2005) menemukan adanya hubungan negatif antara discretionary accrual yang tidak diekspektasi dengan imbal hasil saham di sekitar tanggal pengumuman, dimana hubungan negatif tersebut bervariasi tergantung tingkat kecanggihan investor, dimana reaksi pasar dari investor yang lebih canggih mendahului investor yang tidak canggih. Penelitian lain dilakukan oleh Kusumaningtyas (2012) menyimpulkan bahwa kepemilikan institusional berpengaruh positif terhadap persistensi laba.Berdasarkan uraian tersebut di atas, maka peneliti mengajukan hipotesis $\mathrm{H}_{2}$ sebagai berikut. $\mathrm{H}_{2}$ : Kepemilikan institusional berpengaruh positifpada persistensi laba 


\section{METODE PENELITIAN}

Rancangan sebuah penelitian akan menjelaskan mengenai langkah awal hingga akhir mengenai tata cara dilakukanya penelitian ini dalam memperoleh proses dan hasil yang objektif, efektif, valid, dan efisien. Penelitian ini diawali dengan menetapkan suatu tujuan, yaitu mendapatkan bukti empiris pengaruh komite audit dan kepemilikan institusional pada persistensi laba. Berdasarkan rumusan tujuan yang telah ditetapkan, penelitian ini, mengoperasionalkan 3 (tiga) variabel yaitu persistensi laba sebagai variabel dependen, dan 2 (dua) variabel independen yaitu komite audit serta kepemilikan institusional. Pemilihan sampel dengan metode purposive sampling, data dikumpulkan dengan metode observasi non partisipan, yaitu dengan cara mengumpulkan data sekunder laporan keunagan perushaan manufaktur yang telah dipublikasikan di BEI. Hipotesis dalam penelitian ini akan dianalisis menggunakan regresi linear berganda (multiple regression). Hasil analisis kemudian diinterpretasikan sehingga dapat menjawab permasalahan yang ada. Langkah terakhir yaitu membuat simpulan atas penelitian yang diperoleh serta memberikan saran-saran bagi penelitian selanjutnya.

Penelitian ini mengalisis tentang pengaruh komite audit dan kepemilikan institusional pada persistensi laba, sehingga ruang lingkupnya adalah kualitas laba perusahaan. Data yang dibutuhkan untuk menguji hipotesis diambil dari laporan keuangan perusahaan manufaktur yang terdaftar di BEI tahun 2011 hingga 2012. Alasan menggunakan perusahaan manufaktur untuk menghindari bias karena efek industri. 
Penelitian ini merupakan explanatory research yang menjelaskan hubungan kausal antara variabel dependen dan variabel independen. Dari tiga variabel yang dioperasionalkan, persistensi laba merupakan variabel terikat atau disebut juga variabel dependent dan variabel bebasnya adalah komite audit dan kepemilikan institusional yang disebut juga dengan variabel independent.

Persistensi laba akuntansi adalah revisi dalam laba akuntansi yang diharapkan di masa depan (expected future earnings) yang diimplikasi oleh laba akuntansi tahun berjalan (Francisetal., 2004 dan Pagalung, 2006).Komite audit adalah auditor internal yang dibentuk dewan komisaris, yang bertugas melakukan pemantauan dan evaluasi atas perencanaan dan pelaksanaan pengendalian intern perusahaan. Indikator yang digunakan untuk mengukur komite audit adalah jumlah anggota komite audit pada perusahaan sampel (Verdana Sari, 2013). Kepemilikan institusional merupakan jumlah saham perusahaan yang dimiliki oleh pemegang saham institusional. Kepemilikan institusional diukur dengan jumlah proporsi saham yang dimiliki institusional dibagi dengan jumlah saham yang beredar (Kusumaningtyas, 2012).

Jenis data yang digunakan dalam penelitian ini adalah data sekunder. Data sekunder merupakan sumber data penelitian yang diperoleh secara tidak langsung atau sudah tersedia, yaitu berupa laporan keuangan periode 2011-2012 yang diperoleh dari Bursa Efek Indonesia (BEI) melalui penelusuran langsung situs resmi BEI yaitu www.idx.co.id.

Populasi adalah keseluruhan kelompok orang, peristiwa, atau hal-hal lain yang ingin diteliti. Populasi merupakan keseluruhan obyek (satuan-satuan/ 
individu-individu) yang karakteristiknya hendak teliti. Populasi adalah kumpulan lengkap dari semua elemen (skor, orang, ukuran, dan lain-lain) yang dipelajari (Sekaran,2003). Sedangkan menurut Sugiyono (2008), populasi adalah keseluruhan objek psikologis yang dibatasi oleh kriteria tertentu. Populasi dalam penelitian ini adalah seluruh perusahaan manufaktur yang terdaftar di Bursa Efek Indonesia periode 2011-2012.Sampel adalah bagian dari kumpulan elemen yang diambil dari populasi. Elemen merupakan sebuah anggota tunggal dari populasi. Karena itu, dapat dikatakan bahwa sebuah sampel merupakan subset dari populasi. Sampel terdiri dari beberapa anggota yang dipilih dari populasi (Sekaran, 2003). Dengan kata lain, beberapa, tetapi tidak semua, elemen dari populasi akan membentuk sampel. Dalam penelitian, peneliti dapat menjadikan seluruh obyek atau populasi untuk diteliti tetapi dapat juga mengambil sebagian saja dari keseluruhan objek penelitian untuk diteliti. Pengambilan sampel perusahaan manufaktur dalam penelitian ini dilakukan dengan metode non probability sampling dengan teknis purposive

Data dalam penelitian ini diperoleh melalui metode observasi non partisipan, yaitu dengan cara mengumpulkan data sekunder berupa laporan keuangan perusahaan manufaktur tahun 2011-2012 yang telah dipublikasikan di BEI. Data yang digunakan dalam penelitian ini adalah data sekunder yaitu data laporan keuangan yang dipublikasikan tahunan (annual report) selama tahun 2011-2012.

Analisis data yang digunakan dalam penelitian adalah metode analisis regresi. Dalam analisis regresi akan dikembangkan sebuah estimating 
equation(persamaan regresi) yaitu formula matematika yang mencari nilai variabel dependent dari nilai independent yang diketahui.

Analisis regresi digunakan terutama untuk peramalan, dimana dalam model tersebut terdapat sebuah variabel dependen dan variabel independen. Dalam prakteknya, metode analisis regresi sering dibedakan antara simple regression dan multiple regression. Disebut simple regression jika hanya ada satu variabel independen, sedangkan disebut multiple regression, jika ada lebih dari satu variabel independen(Ghozali, 2001).

Berdasarkan hal tersebut maka metode analisis yang digunakan adalah regresi berganda, yang persamaannya dapat dikemukakan sebagai berikut:

$\mathrm{y}=\alpha+\mathrm{b}_{1} \mathrm{x}_{1}+\mathrm{b}_{2} \mathrm{x}_{2}+\mathrm{e}$

Keterangan:

$$
\begin{aligned}
& \mathrm{y}=\text { Persistensi Laba } \\
& \mathrm{x}_{1} \quad=\text { Komite Audit } \\
& \mathrm{x}_{2}=\text { Kepemilikan Institusional } \\
& \alpha \quad=\text { Konstantan Regresi } \\
& \mathrm{b}_{1}, \mathrm{~b}_{2},=\text { Koefisien Regresi } \\
& \mathrm{e} \quad=\text { Variabel Pengganggu (statistical error) }
\end{aligned}
$$

\section{HASIL DAN PEMBAHASAN}

Statistik deskriptif variabel komite audit, kepemilikan institusional dan presistensi laba pada perusahaan manufaktur yang terdaftar di Bursa Efek Indonesia dan dijadikan sampel dalam penelitian ini dapat dilihat pada Tabel berikut: 
Tabel 1.

Hasil Uji Statistik Deskriptif

\begin{tabular}{|c|c|c|c|}
\hline Keterangan & $\begin{array}{c}\text { Komite Audit } \\
\qquad\left(\mathbf{x}_{1}\right)\end{array}$ & $\begin{array}{c}\text { Kepemilikan } \\
\text { Institusional } \\
\quad\left(\mathbf{x}_{2}\right)\end{array}$ & $\begin{array}{c}\text { Presistensi Laba } \\
\text { (Y) }\end{array}$ \\
\hline Valid & 154 & 154 & 154 \\
\hline Rata - rata & 3,940 & 68,627 & 0,149 \\
\hline Standar Deviasi & 0,990 & 16,211 & 0,179 \\
\hline Minimum & 2,000 & 32,230 & 0,002 \\
\hline Maksimum & 5,000 & 95,400 & 1,006 \\
\hline
\end{tabular}

Berdasarkan Tabel 1 di atas dapat dijelaskan bahwa komite audit memiliki nilai mean atau rata-rata sebesar 3,940 dengan nilai standar deviasi sebesar 0,990. Standart deviasi digunakan untuk menilai penyebaran (dispersi) rata-rata dari sampel, sehingga berarti penyebaran rata-rata sampel tentang komite audit sebesar 0,990. Nilai minimum sebesar 2artinya bahwa dari seluruh jumlah anggota komite audit jumlah anggota terendah sebesar 2 orang. Nilai maksimum sebesar 5artinya bahwa dari seluruh jumlah anggota komite audit perusahaan manufaktur yang terdaftar di Bursa Efek Indonesia memiliki jumlah anggota terbesar sebesar 5 orang.

Variabel kepemilikan institusional memiliki nilai mean atau rata-rata sebesar 68,627 dengan nilai standar deviasi sebesar 16,211. Nilai minimum persentase kepemilikan institusional sebesar 32,230 artinya bahwa dari seluruh nilai kepemilikan institusional nilai persentase terendah sebesar 32,230. Nilai persentase kepemilikan institusional maksimum sebesar 95,400 artinya bahwa dari seluruh nilai kepemilikan institusional perusahaan yang terdaftar di Bursa Efek Indonesia memiliki nilai terbesar sebesar 95,400. 
Variabel presistensi laba memiliki nilai mean atau rata-rata sebesar 0,149 dengan standar deviasi sebesar 0,179. Nilai minimum sebesar 0,002 artinya bahwa dari seluruh nilai presistensi laba nilai terendah sebesar 0,002. Nilai maksimum sebesar 1,006 artinya bahwa dari seluruh nilai presistensi laba perusahaan manufaktur yang terdaftar di Bursa Efek Indonesia memiliki nilai terbesar sebesar 1,006 .

Uji asumsi kalsik merupakan syarat yang harus dipenuhi jika menggunakan analisis regresi dengan tujuan untuk mendapatkan model regresi yang baik dan benar-benar mampu memberikan estimasi yang handal dan tidak bias. Analisis regresi juga menunjukkan arah hubungan antara variabel dependen dengan variabel independen. Teknik estimasi variable dependen yang melandasi independen analisis tersebut disebut Ordinary Least Squares (OLS).

Model regresi yang menggunakan teknik OLS, sering disebut sebagai model regresi linear klasik. Untuk dapat dianalisis hasilnya, model tersebut harus menggunakan asumsi OLS. Terdapat 10 asumsi OLS yang harus dipenuhi, tetapi pada umumnya hanya 4 uji yang harus dilakukan yaitu Uji Normalitas, Uji Heteroskedastisitas, Uji Autokorelasi, dan Uji Multikolinieritas.Pengujian ini dilakukan untuk meyakini bahwa model regresi yang diperoleh mempunyai kemampuan untuk memprediksi, dan kemanfaatan dalam pengambilan keputusan.

Multikolinieritasadalah suatu keadaan di mana salah satu atau lebih variabel independen dapat dinyatakan sebagai kombinasi linier dari variabel independen lainnya. Cara yang digunakan untuk mendeteksi ada tidaknya multikolinieritasadalah dengan melakukan regresi antar variabel penjelas. Jika 
signifikan berarti terdapat multikolinieritas. Untuk menguji multikolinieritas dengan vasilitas yang disediakan SPSS yaitu dengan melihat nilai VIF dari masing-masing variabel. Jika nilai VIF lebih rendah dari 10, maka dapat disimpulkan bahwa tidak ada multikolinieritas yang serius antara variabel independen dalam model. Dengan melihat nilai VIF dalam model regresi dapat diketahui bahwa masing-masing variabel tidak mengandung adanya gejala multikolinieritas karena mempunyai nilai VIF yang lebih rendah dari 10 (Tabel 2).

Tabel 2.

Ringkasan Hasil Pengujian Multikolinieritas

\begin{tabular}{|c|c|c|c|}
\hline \multirow{2}{*}{\multicolumn{2}{|c|}{ Model }} & \multicolumn{2}{|c|}{ Collinearity Statistics } \\
\hline & & Tolerance & VIF \\
\hline \multirow[t]{3}{*}{1} & (Constant) & & \\
\hline & Komite Audit $\left(\mathrm{x}_{1}\right)$ & 0,995 & 1,005 \\
\hline & Kepemilikan Institusional $\left(\mathrm{x}_{2}\right)$ & 0,995 & 1,005 \\
\hline
\end{tabular}

Tabel 2 memperlihatkan bahwa hasil perhitungan nilai tolerance menunjukkan tidak ada variabel independen yang memiliki nilai tolerance kurang dari 0,10 yang berarti tidak ada korelasi antar variabel independen yang nilainya lebih dari 95\%. Hasil perhitungan Variance Inflation Factor (VIF) juga menunjukkan hal yang sama, tidak ada satu variabel independen yang memiliki nilai VIF lebih dari 10. Jadi dapat disimpulkan bahwa tidak ada Multikolonieritas antar variabel independen dalam model regresi.

Uji autokerelasi yang digunakan dalam penelitian ini adalah Uji DurbinWatson (DW-test). Uji Durbin Watson hanya digunakan untuk autokorelasi tingkat satu (first order autocorrelation) dan mensyaratkan adanya intercept (konstanta) dalam model regresi dan tidak ada variabel lagi di antara variabel indepeden. Selanjutnya uji autokerelasi Durbin-Watson (DW-test) dilakukan 
dengan menggunakan bantuan Program SPSS ver 19 for windows, hasil olah data terlihat seperti Tabel 3 berikut.

Tabel 3.

Hasil Uji Autokorelasi dengan Durbin-Watson (DW Test)

\begin{tabular}{llrrrr}
\hline Model & R & R Square & $\begin{array}{c}\text { Adjusted R } \\
\text { Square }\end{array}$ & $\begin{array}{c}\text { Std. Error of the } \\
\text { Estimate }\end{array}$ & Durbin-Watson \\
\hline 1 & $0,729^{\mathrm{a}}$ & 0,531 & 0,525 & 0,123946 & 1,964 \\
\hline
\end{tabular}

Sumber:data sekunder diolah, 2015

Tabel 3 memperlihatkan bahwa nilai DW sebesar 1,806. Nilai ini akan dibandingkan dengan nilai tabel dengan menggunakan nilai signifikansi 5\%, dengan jumlah sampel sebanyak 77 (n) dan jumlah variabel independen $2(\mathrm{k}=2)$ sebagai berikut:

Tabel 4.

Tabel Pengambilan Keputusan Uji Autokorelasi

\begin{tabular}{lcc}
\hline \multicolumn{1}{c}{ Kesimpulan } & Keputusan & Jika \\
\hline Ada autokorelasi & Tolak & Kurang dari 1,08 \\
Tanpa kesimpulan & No desicision & $1,08 \mathrm{~s} / \mathrm{d} 1,66$ \\
Tidak ada autokorelasi & Tdk Tolak & $1,66 \mathrm{~s} / \mathrm{d} 2,34$ \\
Tanpa kesimpulan & No desicision & $2,34 \mathrm{~s} / \mathrm{d} 2,92$ \\
Ada korelasi & Ditolak & Lebih dari 2,92 \\
\hline
\end{tabular}

Sumber: Ghozali (2006:96)

Nilai DW 1,964lebih besar dari batas bawah (du) 1,66 dan kurang dari batas atas 2,34 (4-du), maka dapat disimpulkan bahwa tidak ada autokorelasi positif atau negatif. Dengan demikian dapat disimpulkan tidak terdapat autokorelasi.

Uji heterokedastisitas bertujuan menguji apakah dalam model regresi terjadi ketidaksamaan variance dari residual suatu pengamatan ke pengamatan yang lain yang lain. Jika variance dari residual satu pengamatan ke pengamatan yang lain tetap, maka disebut homokedastisitas dan jika berbeda disebut heterokedastisitas. Selanjutnya uji heterokedastisitas dengan menggunakan 
Glejser dilakukan dengan menggunakan bantuan Program SPSS ver 19 for windows, hasil olah data terlihat seperti Tabel 5 berikut.

Tabel 5.

Hasil Uji Heterokedastisitas dengan Glejser

\begin{tabular}{|c|c|c|c|c|c|}
\hline & & \multicolumn{2}{|c|}{$\begin{array}{c}\text { Unstandardized } \\
\text { Coefficients }\end{array}$} & \multirow[b]{2}{*}{$\mathbf{t}$} & \multirow[b]{2}{*}{ Sig. } \\
\hline \multicolumn{2}{|c|}{ Model } & B & Std. Error & & \\
\hline \multirow[t]{3}{*}{1} & (Constant) & 0,315 & 0,057 & 5,558 & 0,207 \\
\hline & Komite Audit $\left(\mathrm{x}_{1}\right)$ & $-0,066$ & 0,009 & $-7,063$ & 0,562 \\
\hline & $\begin{array}{l}\text { Kepemilikan Institusional } \\
\left(\mathrm{x}_{2}\right)\end{array}$ & 0,002 & 0,001 & 3,724 & 0,294 \\
\hline
\end{tabular}

Tabel 5 menunjukkan bahwa tidak ada satupun variabel independen yang signifikan secara statistik mempengaruhi variabel dependen nilai absolut Y atau | Y |. Hal ini terlihat dari probabilitas signifikansinya di atas 0,05 atau di atas tingkat kepercayaan 5\%, jadi dapat disimpulkan model regresi tidak mengandung adanya heterokedastisitas.

Uji normalitas bertujuan untuk menguji apakah dalam model regresi, variabel, pengganggu atau residual memiliki distribusi normal. Untuk menguji normalitas dalam penelitian ini peneliti menggunakan uji statistik dengan parametrik Kolmogrorov-Smirnow test (K-S) dengan menggunakan bantuan Program SPSS ver 19 for windows, hasil olah data terlihat seperti Tabel 6 berikut.

Tabel 6.

Hasil Normalitas dengan Kolmogrorov-Smirnow Test (K-S)

\begin{tabular}{llr}
\hline & & $\begin{array}{r}\text { Unstandardized } \\
\text { Predicted Value }\end{array}$ \\
\hline $\mathrm{N}$ & & 154 \\
Normal Parameters $^{\mathrm{a}}$ & Mean & 0,19906 \\
& Std, Deviation & 0,144254 \\
Most Extreme Differences & Absolute & 0,092
\end{tabular}




\begin{tabular}{lcr} 
& Positive & 0,092 \\
& Negative & $-0,046$ \\
Kolmogorov-Smirnov Z & & 1,145 \\
Asymp. Sig. (2-tailed) & 0,145 \\
\hline Sumber: data sekunder diolah, 2015 &
\end{tabular}

Dari perhitungan di atas diperoleh nilai Asymp.Sig. (2-tailed) 0,145 dengan nilai Kolmogorov-Snirnov Z 1,145. Hasil dari nilai tersebut lebih besar dari tingkat alpha (Asymp.Sig. > 0,05), sehingga dapat disimpulkan bahwa seluruh data variabel dalam penelitian ini berdistribusi normal.

Penelitian ini menguji pengaruh komite audit, kepemilikan institusional pada persistensi laba. Hasil analisis regresi linier berganda yang dihasilkan dengan bantuan program SPSS ver. 16 for windows dapat dilihat dalam Tabel 7 berikut.

Tabel 7.

Hasil Analisis Regresi Berganda

\begin{tabular}{|c|c|c|c|c|}
\hline \multirow[b]{2}{*}{ Model } & \multicolumn{2}{|c|}{$\begin{array}{c}\text { Unstandardized } \\
\text { Coefficients }\end{array}$} & \multirow[b]{2}{*}{$\mathbf{t}$} & \multirow[b]{2}{*}{ Sig. } \\
\hline & B & Std. Error & & \\
\hline 1 (Constant) & 0,347 & 0,061 & 5,673 & 0,000 \\
\hline Komite Audit $\left(\mathrm{x}_{1}\right)$ & $-0,114$ & 0,010 & $-11,238$ & 0,000 \\
\hline $\begin{array}{l}\text { Kepemilikan } \\
\text { Institusional } \quad\left(\mathrm{x}_{2}\right)\end{array}$ & 0,004 & 0,001 & 5,867 & 0,000 \\
\hline ( $\mathbf{R}^{2}$ Adjusted) & & 0,525 & & \\
\hline $\mathbf{F}$ & & $85,579(0,00)$ & & \\
\hline
\end{tabular}

Sumber: data sekunder diolah, 2015

Koefisien determinasi mengukur seberapa jauh kemampuan model menerangkan variansi dependen (Ghozali, 2012;92). Nilai koefisien determinasi berada diantara nol dan satu. Hasil analisis menunjukkan nilai $\mathrm{R}^{2}$ adjusted sebesar 0,525 yang berarti kemampuan komite audit dan komisaris independen menjelaskan variansi persistensi laba sebesar 52,5\% dan sisanya sebesar 47,5 \%dijelaskan oleh variable lain yang tidak terdapat dalam model. 
Uji statistik $\mathrm{t}$ menunjukkan besarnya kontribusi pengaruh variabel independen yaitu komite audit dan kepemilikan institusional secara individu pada persistensi laba.

Berdasarkan hasil uji goodness of fit maka model persamaan regresi yang digunakan untuk menguji hipotesis layak digunakan.

$\mathrm{y}=\alpha+\mathrm{b}_{1} \mathrm{x}_{1}+\mathrm{b}_{2} \mathrm{x}_{2}+\mathrm{e}$

$$
\mathrm{y}=0,347-0,114 \mathrm{x}_{1}+0,004 \mathrm{x}_{2}+\mathrm{e}
$$

Keterangan:

$$
\begin{aligned}
& \mathrm{y}=\text { Persistensi Laba } \\
& \mathrm{x}_{1} \quad=\text { Komite Audit } \\
& \mathrm{x}_{2}=\text { Kepemilikan Institusional } \\
& \alpha=\text { Konstantan Regresi } \\
& \mathrm{b}_{1}, \mathrm{~b}_{2},=\text { Koefisien Regresi } \\
& \mathrm{e} \quad=\text { Variabel Pengganggu (statistical error) }
\end{aligned}
$$

Dari model regresi tersebut diperoleh konstanta sebesar 0,347. Hal ini berarti bahwa tanpa adanya komite audit dan kepemilikan institusional akan terjadi perubahan presitensi laba sebesar $34,7 \%$. Selanjutnya koefisien regresi komite audit sebesar $-0,114$ dan bertanda negatif,hal ini berarti bahwa setiap perubahan komite audit satu persen dengan asumsi variabel lainnya tetap maka perubahan presistensi laba akan mengalami perubahan (penurunan) sebesar 11,49\%. Sedangkan kepemilikan institusionalmempunyai koefisien regresi sebesar 0,004 dan bertanda positif, berarti setiap perubahan kepemilikan institusional satu persen dengan asumsi variabel lainnya tetap maka perubahan presistensi laba akan mengalami perubahan sebesar $0,4 \%$ dengan arah yang sama.

Berdasarkan hasil regresi yang tersaji dalam Tabel 7 memperlihatkan bahwa nilai probabilitas ( $p$-value) signifikan sebesar 0,000 namun koefisien beta (b) 
memiliki nilai negatif $(-0,114)$, sehingga hasil menunjukkan bahwa nilai koefisien beta komite audit pada persistensi laba berada pada daerah penolakan hipotesis. Dengan demikian hipotesis 1 yang menyatakan bahwa "Komite audit berpengaruh positif pada persistensi laba" tidak dapat diterima..

Berdasarkan hasil regresi yang tersaji dalam Tabel 7 memperlihatkan bahwa nilai probabilitas signifikansi atau p-value pengaruh kepemilikan institusional pada persistensi laba adalah 0.000 atau lebih kecil dari 0.05 atau 5\% dengan koefisien regresi adalah positif 0,004 . Dengan demikian hipotesis 2 yang menyatakan bahwa "Kepemilikan institusional berpengaruh positif pada persistensi laba" tidak dapat ditolak.

Hasil analisis mengandung arti bahwa semakin banyak jumlah komite audit yang dimiliki maka persistensi laba akan cenderung menurun, hal ini mungkin disebabkan karena ketika jumlah komite audit di dalam suatu perusahaan makin banyak, maka pengawasan dan pengendalian yang dilakukan oleh komite audit harus semakin mempertimbangkan banyak pandangan yang berasal dari berbagai sudut pandang anggota dengan variasi background pendidikan yang berbeda, dan dapat mengakibatkan ketidak efektifan kerja komite audit sehingga tingkat persistensi laba juga akan semakin menurun dan semakin rendah kualitas laba yang dilaporkan. Kemungkinan lainnya tidak semua anggota komite audit mempunyai keahlian dibidang akuntansi dan keuangan sehingga dapat menurunkan unsur relevansi dalam laporan keuangan sehingga prediktabilitas laporan keuangan cenderung menurun. Tingkat keahlian dibidang akuntansi dan keuangan seluruh anggota komite audit juga berdampak pada proses pengawasan 
laporan keuangan yang pada akhirnya akan mempengaruhi kualitas laporan keuangan tersebut. Hasil ini mendukung penelitian Fibri (2013) yang menunjukkan bahwa kepemilikan manajerial tidak mempunyai hubungan yang signifikan terhadap kualitas laba. Hal ini dikuatkan hasil penelitian Verdana Sari (2013) yang menunjukkan bahwa kepemilikan institusional, proporsi dewan komisaris independen, kepemilikan manajerial, dan komite audit tidak berpengaruh terhadap kualitas laba. Fathia Anissa (2012) juga mengungkapkan bahwa komite audit dan kepemilikan institusional tidak berpengaruh pada kualitas laba.

Hasil pengujian hipotesis 2 yang menyatakan bahwa "Kepemilikan institusional berpengaruh pada persistensi laba" tidak dapat ditolak. Hasil ini juga mengandung arti bahwa semakin banyak jumlah saham yang dimiliki pemegang saham institusi, maka persistensi laba akan cenderung meningkat, karena kekuasaan yang dimiliki pemegang saham konstitusi semakin tinggi dan mereka dapat melakukan monitoring dengan lebih baik sehingga semakin kecil kemungkinan manajemen melakukan earnings restatement atau semakin tinggi kualitas laba yang dilaporkan. Hasil yang dicapai mendukung studi yang lakukan oleh Kouki dan Guizani (2009) menyatakan bahwa kepemilikan institusional yang besar merupakan cara untuk mengawasi manajer. Peningkatan kepemilikan institusional dapat mengurangi agency cost atas debt dan insider ownership karena semakin besar kepemilikan institusional maka akan dapat mengurangi terjadinya konflik antara kreditur dan manajer, dan akhirnya dapat menekan biaya keagenan. Komunitas bisnis menaruh perhatian yang besar untuk meningkatkan 
kepemilikan institusional, sehingga dapat lebih banyak mempengaruhi kebijakan perusahaan. Institusi dengan kepemilikan saham yang relatif besar dalam perusahaan mungkin akan mempercepat manajemen perusahaan untuk menyajikan pengungkapan secara sukarela. Hal ini terjadi karena investor institusional dapat melakukan pengawasan dan dianggap sebagai investor yang canggih (sophisticated investors), yang tidak mudah dibodohi oleh tindakan manajer. Hasil yang dicapai juga mendukung studi Schleiver dan Vishny (2006), menyatakan bahwa kepemilikan institusional sangat berperan dalam mengawasi perilaku manajer dan memaksa manajer untuk lebih berhati-hati dalam mengambil keputusan yang oportunis. Kepemilikan institusional memiliki kemampuan untuk mengendalikan pihak manajemen melalui proses monitoring secara efektif sehingga dapat mempengaruhi persistensi laba. Persentase saham tertentu yang dimiliki oleh institusi dapat mempengaruhi proses penyusunan laporan keuangan yang tidak menutup kemungkinan terdapat akrualisasi sesuai kepentingan pihak manajemen. Hasil yang dicapai juga mendukung studi yang dilakukan Cornertt et al. (2006) yang menyimpulkan bahwa tindakan pengawasan perusahaan oleh kepemilikan institusional dapat mendorong manajer untuk lebih memfokuskan perhatiannya terhadap kinerja perusahaan sehingga akan mengurangi perilaku opportunistik atau mementingkan diri sendiri. Juga penelitian dilakukan oleh Kusumaningtyas (2012) menyimpulkan bahwa kepemilikan institusional berpengaruh positif terhadap persistensi laba. 


\section{SIMPULAN DAN SARAN}

Berdasarkan hasil analisis bab-bab sebelumnya maka dapat dibuat simpulan bahwa komite audit berpengaruh pada presistensi laba namun arahnya negatif. Hal ini bermakna bahwa semakin banyak jumlah komite audit yang dimiliki maka persistensi laba akan menurun, karena masing masing anggota komite audit memiliki keahlian dibidang akuntansi berbeda beda sehingga mempengaruhi kwalitas komite audit itu sendiri. Kepemilikan Institusional berpengaruh positif pada presistensi laba. Hal ini bermakna bahwa, semakin banyak jumlah saham yang dimiliki pemegang saham institusi, maka persistensi laba akan cenderung meningkat, karena kekuasaan yang dimiliki pemegang saham konstitusi semakin tinggi dan para investor institusional dapat langsung terlibat dalam pengambilan keputusan strategis sehingga mendorong peningkatan dan pengawasan yang lebih optimal.

Berdasarkan simpulan di atas, maka saran-saran yang dapat diberikan adalah sebagai berikut.Bagi perusahaan diharapkan dapat memahami keberadaan komite audit baik dari sisi jumlah maupun latar belakang anggota komite audit supaya dapat meningkatkan efektifitas kerja sehingga persistensi laba bisa tercapai. Bagi pemilik mayoritas, keberadaan anggota dewan komisaris yang berasal dari pemegang saham institusi memiliki peran penting dalam melakukan kontrol terhadap aktivitas manajemen, karena ada pihak yang paham diajak melakukan monitoring sehingga tercipta tim kerja yang baik pula dalam mengembangkan perusahaan dalam jangka panjang. Jumlah $\mathrm{R}^{2}$ (Adjusted) adalah $52,5 \%$ yang berarti masih terdapat variabel lainnya yang berpengaruh pada 
persistensi laba seperti variable volatilitas arus kas, besaran akrual, volatilitas penjualan, tingkat hutang, siklus operasi, dan ukuran perusahaan. Peneliti selanjutnya diharapkan dapat mengembangkan penelitian ini dengan penambahan variabel tersebut.

\section{REFERENSI}

Bapepam, 2000. Pembentukan Komite Audit, Surat Edaran Bapepam No. SE.03/PM/2000

Bapepam. 2004. Peraturan IX.1.5. 2004 tentang "Pembentukan dan Pedoman Pelaksanaan Kerja Komite Audit". http://www.bapepamlk.depkeu.go.id/old/hukum/peraturan/emiten/. Diakses tanggal 17 Oktober 2013.

Bartov, Eli., 1993. "The Timing of Asset Sales and earning Manipulation". The Accounting review, Vol. 68, No.4 (October), pp.159-855.

Beneish,M., and M. Vargus. 2002. "Insider Trading, Earning Quality, and Accrual Mispricing”. The Accounting Riview, 77 (4), 755-791.

Boediono, Gideon SB. 2005. "Kualitas Laba : Studi Pengaruh MekanismeCorporate Governance dan Dampak Manajemen Laba denganMenggunakan Analisis Jalur.” Simposium Nasional Akuntansi VIII.

Chan, K., L. Chan, N. Jegadeesh, and J. Lakonishok. 2004. Earnings quality and stock return. Working paper, University of Illinois at Urbana-Champaign.

Chandarin, G. 2001. Laba (Rugi) Selisih Kurs sebagai Salah Satu Faktor yang Mempengaruhi Koefisien Respon Laba Akuntansi: Bukti Empiris dari Pasar Modal Indonesia. Disertasi. Universitas Gadjah Mada, Yogyakarta.

Chtourou, SM., Jean Bedard, and Lucie Courteau. 2001. "CorporateGovernance and Earnings Management." http://papers.ssrn.com/. Diakses tanggal 5 Januari 2011.

Cornett M.M., J Marcuss, Saunders, and Tehranian H. 2006. "EarningsManagement, Corporate Governance, and True FinancialPerformance." http://papers.ssrn.com/. Diakses tanggal 5 Januari 2011.

Darraough, M.N. 1993. "Disclosure Policy and Competition: Cournot vs Bertrand". The Accounting Review, Vol. 68, No. 3, pp.534-561. 
Dechow, P. and I. Dichev. 2002. "The Quality of Accruals and Earninga: The Role of Accruals Estimation Errors". The Accounting Review, 77 (Supplement), 35-59.

Fathia Annisa. 2012. "Pengaruh Good Corporate Governance Terhadap Kualitas Laba (Studi Empiris Pada Perusahaan Sektor Keuangan Yang Terdaftar Di Bursa Efek Indonesia (BEI) Periode 2009-2011)”. Jurnal Publikasi.

Francis, J., R. LaFond, P. Olsson, and K. Schipper. 2004. "Costs of Equity and Earnings Attributes". The Accounting Revew, 79 (4), 967-1010.

Ghozali, I. 2001. Aplikasi Analisis Multivariate dengan Program SPSS. Edisi II: Badan Penerbit Universitas Diponegoro, Semarang.

Hartzell, Jay C. dan Laura T. Starks. 2003. "Institutional Investors and Executive Compensation". The Journal Of Finance. Vol. LVIII, No. 6.

Hayn, C. 1995. "The Information Content of Losses". Journal of Accounting and Economics, Vol. 20,pp. 125-153.

Khafid, Muhammad. 2012. "Pengaruh Tata Kelola Perusahaan (Corporate Governance) dan Struktur Kepemilikan Terhadap Persentasi Laba”. Jurnal Dinamika Akutansi, Vol. 4, No. 2, hlm. 139-148.

Klein, A. 2002. "Audit Committee, Board of Director Characteristics, and Earnings Management". Journal of Accounting and Economic., 32: 375400.

Komite Nasional Kebijakan Governance. 2013. Pedoman Umum Good Corporate Governance Indonesia ,Jakarta: KNKG, 2013.

Kouki, Mondher. and Moncef Guizani. 2009. "Ownership Structure andDividend Policy Evidence from the Tunisian Stock Market. European Journal of Scientific Research. http://www.eurojournals.com/ejsr.htm. Diakses tanggal 20 Maret 2014.

Lev, B.and R., Thiagarajan, 1993. Fundamental Information Analysis. Journal of Accounting Research, 31, (2), 190-215.

Lin, J.W., Li, J.F. and Yang, S.Y. 2006. "The Effect of Audit CommitteePerformance on Earnings Quality. " Managerial Auditing Journal, 21(9):921933.

Meythi. 2006. Pengaruh Arus Kas Operasi Terhadap Harga Saham dengan Presistensi Laba Sebagai Variabel Intervening. Simposium Nasional Akuntansi 9, Padang.

OECD. 2006. "OECD Principles of Corporate Governance". 
I Made Sujana, Gerianta Wirawan Yasa dan I Dewa Nym. Badera.Pengaruh Komite .......

Pagalung, G. 2006. Kualitas Informasi Laba: Faktor-Faktor Pennentu dan Konsekwensi Ekonominya. Disertasi. Universitas Gajah mada, Yogyakarta.

Penman, S.H. 2001.On Comparing Cash Flow and Accrual Accounting Models For Use in Equity Valuation. Working paper, www.ssrn.com.

Penman, S.H. and X.J. Zhang. 2002. "Accounting Conservatism, the Quality of Earnings, and Stock Return", The Accounting Review, Vol. 77, No. 2, April: 237-264.

Richardson, S. 2003. "Earnings Quality and Short Sellers". Supplement. Accounting Horizons, Vol. 17, pp. 49-61.

Richardson, S., R. Sloan, M. Soliman, I. Tuna. 2001. Information in Accruals About the Quality of Earning. Workinhy Paper, University, of Michigan business school.

Scheileifer dan Vishny. 2006. "Corporate Governance Principles ofCorporate Governance in Greece" An International Revie, Vol 9, Issue2.

Sekaran, Uma, 2003, "Research Methods for Business: A Skill Building Approach", John Wiley \& Sons, Inc., New York: 86-118.

Siregar, Sylvia Veronica N.P dan Siddharta Utama. 2005. "PengaruhStruktur Kepemilikan, Ukuran Perusahaan, dan Praktek CorporateGovernance Terhadap Pengelolaan Laba (Earnings Management)." Proceeding Simposium Nasional Akuntansi VIII.

Sloan, R.G., 1996. "Do Stock Princes Fully Reflect Information in Accruals and Cash Flow About Future Earning?". The Accounting Review, 71 (3), 289315.

Solomon, J., dan Solomon, A. 2004, Corporate Governance and Accountability, John Wiley \& Sons, Ltd.

Sugiyono, 2008, Metode Penelitian Bisnis, Bandung: CV. Alfabeta.

Sutojo, Siswanto. 2005. Good Corporate Governance: Tata kelola Perusahaan yang Sehat.

Verdana Sari, Akhmad Riduwan 2013, Pengaruh Corporate Goverment Terhadap Nilai Perusahaan: Kualitas Laba sebagai Variabel Intervening, Jurnal Ilmu Riset Akuntansi, Volume 1 No 1-2013

Wijayanti, Handayani Tri. 2006. Analisis Pengaruh Perbedaan antara Laba Akuntansi dan Laba Fiskal terhadap Persistensi Laba, Akrual dan Arus Kas. Simposium Nasional Akuntansi 9. Padang. 